\title{
Design and evaluation of a unique RT-qPCR assay for diagnostic quality control assessment that is applicable to pathogen detection in three species of salmonid fish
}

Dagoberto Sepúlveda ${ }^{1,2,6}$, Harry Bohle ${ }^{3}$, Álvaro Labra ${ }^{2,4}$, Horst Grothusen ${ }^{3}$ and Sergio H Marshall ${ }^{1,25^{*}}$

\begin{abstract}
Background: The detection of pathogens at early stages of infection is a key point for disease control in aquaculture. Therefore, accurate diagnostic procedures are a must. Real-time PCR has been a mainstay in diagnostics over the years due to its speed, specificity, sensitivity, reproducibility and throughput; as such, real-time PCR is a target for improvement. Nevertheless, to validate a novel diagnostic tool, correct setup of the assay, including proper endogenous controls to evaluate the quantity and quality of the samples and to detect possible sample degradation, is compulsory. This work aims to design a unique RT-qPCR assay for pathogen detection in the three salmonid species reared in Chile. The assay uses elongation factor 1 alpha as the single endogenous control, thus avoiding the need for multiple endogenous controls, as well as multiple validations and non-comparable quality control parameters.

Results: The in vivo and in vitro analyses of samples from Salmo salar, Oncorhynchus mykiss and Oncorhynchus kisutch showed that when primers were accurately selected to target conserved regions of the elongation factor 1 alpha (ELF1a) gene, a single novel RT-qPCR assay yielding similar and reproducible Ct values between the three species could be designed. The opposite occurred when an assay originally designed for Salmo salar was tested in samples from the two species of the genus Oncorhynchus.
\end{abstract}

Conclusions: Here, we report the design and evaluation of an accurate trans-species RT-qPCR assay that uses the elongation factor 1 alpha (ELF1a) gene as an endogenous control and is applicable for diagnostic purposes in samples obtained from the three salmonid species reared in Chile.

Keywords: Elongation Factor 1 alpha, ELF1a, Endogenous control, Fish disease, Fish virus, Real-time PCR, RT-qPCR

\section{Background}

In nature, fish are exposed to a wide variety of microorganisms of bacterial, viral or fungal origins, many of which are capable of causing disease. When fish are reared under controlled conditions, the menace of disease-causing agents increases significantly because confined fish are also exposed to a number of stressors, such as handling,

\footnotetext{
* Correspondence: smarshal@ucv.cl

'Laboratorio de Genética e Inmunología Molecular, Instituto de Biología,

Facultad de Ciencias, Pontificia Universidad Católica de Valparaíso, Valparaíso, Chile

2Laboratorio de Patógenos Acuícolas, Núcleo Biotecnología Curauma,

Pontificia Universidad Católica de Valparaíso, Valparaíso, Chile

Full list of author information is available at the end of the article
}

transport, poor water quality and overstocking. These stressors, together with other weaknesses such as physiological unbalance or nutritional deficiency, challenge homeostasis and thus allow opportunistic infections to proceed [1]. As a result, diseases represent a major economic cost, especially when the impact is on fish of high commercial value [2]. Some of these pathogens are fastidious and highly aggressive, causing high mortality rates, while others persist in fish, representing a potential danger to managed fish in aquaculture if an outburst occurs close to harvest. In this scheme, accurate pathogen detection, ideally in the early stages of infection, is necessary in order to design adequate strategies to control key infectious

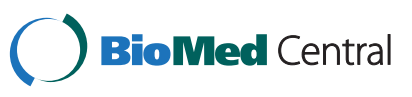


diseases that seriously threaten the sustainability of aquaculture. One of the techniques that has consistently been transversal in specifically detecting sequences of target pathogens in humans, plants and animals, including fish, is real-time PCR because of its sensitivity, specificity, speed, throughput and reproducibility [3]. In the aquaculture environment, this technique has been successfully used to detect, among other pathogens, viral hemorrhagic septicemia virus (VHSV) [4], infectious hematopoietic necrosis virus (IHNV) [5], salmon alphavirus (SAV) [6], Piscirickettsia salmonis [7-9], Renibacterium salmoninarum [10], infectious salmon anemia virus (ISAV) [11], and infectious pancreatic necrosis virus (IPNV) [12].

Nevertheless, massive application of this technique requires correct setup of the assay, including the necessary controls, for unequivocal interpretation of the results. Among the most important of these controls is an endogenous reference control that is able to provide information not only about the amount of the detectable target nucleic acid in the sample to be analyzed but also about the sample integrity in order to accurately validate processes such as sampling, transport, and nucleic acid isolation, allowing degradation of the samples to be detected $[11,13]$. This is not a simple task to achieve, as determining the proper endogenous levels of a given marker molecule depends on a number of variables, including the target organ and the type of nucleic acid to be detected. In the case of targeting viral RNA, specifically for the diagnosis of the ISA virus in infected tissues of fish, the use of the elongation factor 1 alpha (ELF1 $\alpha$ ) has been demonstrated to be a reliable reference RNA-expressed control because of its stability and constant expression in Salmo salar organs, in both the presence and the absence of the ISA virus [11,14-16]. Additionally, because of its relevance, ELF1 $\alpha$ has also been recommended as a housekeeping gene for gene expression analyses of other salmonid fish-related pathogens, such as Piscirickettsia salmonis [17], SAV [18], and VHSV [4].

Although an ELF1 $\alpha$-driven assay has been successfully used for ISAV detection in Salmo salar samples [11,14], it is also known to have a highly variable performance when used for the diagnosis of other reared salmonid species, particularly Oncorhynchus kisutch and Oncorhynchus mykiss, which together with Salmo salar, constitute the economically important species cultivated in Chile. For this reason, we considered it imperative to analyze the sequence variability associated with a presumptive polymorphism in the ELF1 $\alpha$ coding sequence of the three salmonid species cultivated in Chile; we would then be able to design a transversal RT-qPCR assay that would allow us to use the same parameters to accurately determine the quantity and quality of the samples, regardless of the salmonid species tested and thereby reliably diagnose RNA pathogens.

\section{Results and discussion}

\section{Sequence variability evaluation}

Because salmon production in Chile relies on two additional species that are different from Salmo salar, we decided to compare the potential nucleotide variability in the RT-qPCR amplifiable target region of ELF1 $\alpha[11,14]$ in all three salmonid fish species reared in Chile, as variability in this region could be causing the species-dependent performance of the assay. cDNAs from 20 tissue samples from Oncorhynchus mykiss and Oncorhynchus kisutch were amplified, and the PCR products were sequenced directly to avoid any sequence selection bias that might result from a plasmid cloning process. The electropherogram profiles (data not shown) consistently showed double peaks at four positions on the amplified region: one at the forward primer annealing position, one at the probe annealing position, and two at the reverse primer annealing position (Figure 1). It is particularly relevant that one of the two mismatches detected by the reverse primer was situated at the 3 ' end, which could seriously interfere with the efficiency of the amplification process [19]. According to previous studies, the presence of double peaks in the electropherograms could be explained by the presence of heterozygosity, SNPs or sequence insertions [20-22]. Although not the main focus of this work, the information obtained here allowed us to design novel transversal primers and probes that are able to specifically amplify and detect selected ELF1 $\alpha$ coding sequences in the three fish species reared in Chile with the same degree of accuracy.

To determine whether differences detected in the amplification could be overcome to generate a transversal RT-qPCR reaction, multiple alignments were made with the sequences derived from this study, as well as with those available in the GenBank database. Figure 1 shows that using the BioEdit software [24], it was possible to identify two types of nucleotide variations where we could detect double peaks in the electropherograms. First, an "intragenus conserved variation" consisted of a cytidine residue in the forward primer annealing position for all species of the Salmo genus analyzed, which was changed to a Thymidine residue for the two species of the Oncorhynchus genus analyzed (blue arrow in Figure 1). Additionally, we identified an "intragenus nonconserved variation," which did not correlate with specific changes in each genus (red arrow in Figure 1).

\section{Design of a new transversal assay}

Considering the nucleotide variations previously shown, we were in a position to design a new assay to detect ELF1 $\alpha$ in all salmonid fish species cultivated in Chile. It is well-known that nucleotide variations in the annealing positions of primers and probes affect the sensitivity and efficiency of this type of reaction, as they can lead to putative 


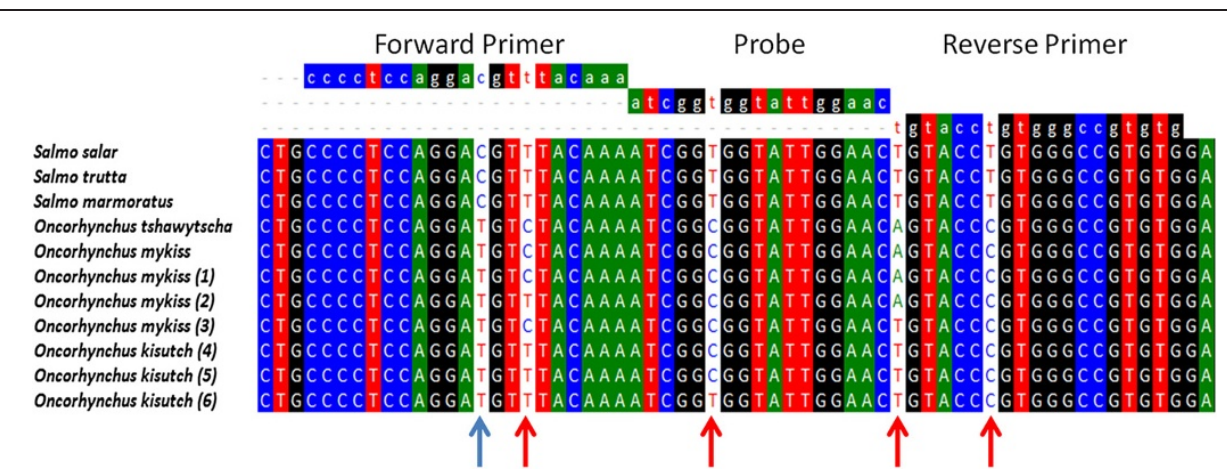

Figure 1 Analysis of nucleotide variation between different salmonid species. A multiple alignment was made using ClustalW [23] using the Bioedit software [24]. Top, primers and probe used in the current assay (ELF1a) [14]. The first 5 species sequences are available in the GenBank database; S. salar [BT060430], S. marmoratus [EU853442], S. trutta [EF406271], O. tshawytscha [FJ890356] and O. mykiss [AF498320]. Samples labeled with numbers from 1 to 6 were representative of sequences obtained from Oncorhynchus samples in this work. Blue arrow shows the Intragenus conserved variation and red arrow show the Intragenus non-conserved variations.

underestimations of the actual amount of template present in a sample. Although it may seem trivial, mismatches between primers and probes on a given template actually constitutes an important issue to consider in the generation of a highly specific and reproducible detection assay $[19,25]$. We chose to use degenerate nucleotides in the probes and primers involving internal nucleotide variations as a testing strategy. Additionally, we moved the reverse primer one nucleotide downstream from the probe, taking into account that a variation in the 3 ' end could dramatically affect the performance of the assay. Table 1 shows the three assay conditions evaluated and compared in this work. Assay $\mathrm{N}^{\circ} 1(\mathrm{ELF} 1 \alpha)$ is the assay currently in use [14]. Assay $\mathrm{N}^{\circ} 2$ (ELF1 $\alpha$ GIM-1), uses the same sequences as assay $\mathrm{N}^{\circ} 1$, but incorporates degeneracy in the variable positions. Assay $\mathrm{N}^{\circ} 3$ (ELF1 $\alpha$ GIM-2) employs different primers to eliminate the 3 ' end degeneration in the original reverse primer. The same probe was used for assays $\mathrm{N}^{\circ} 2$ and $\mathrm{N}^{\circ} 3$, which differ from each other only in terms of the primers used.

\section{Evaluation of the alternative new assays}

Initially, performances of the two novel alternative assays $\left(\mathrm{N}^{\circ} 2\right.$ and $\left.\mathrm{N}^{\circ} 3\right)$ were compared against the classical one $\left(\mathrm{N}^{\circ} 1\right)$ using templates obtained from S. salar, O. kisutch and O. mykiss tissue samples. For this comparison, the detecting probe was used without an MGB or LNA system [13]. Under these conditions, the probe displayed a $\mathrm{Tm}$ value of $49.9^{\circ} \mathrm{C}$, which was calculated using OligoCalc [26] and which suggested low stability in the annealing process of the probe and template. This allowed us to evaluate the performance of the assay based on the condition that any mismatch could affect the results considerably, thus making it easier to detect any improvement.

The results of the three assays in Table 2 clearly show that assay $\mathrm{N}^{\circ} 3$ performed better than assays $\mathrm{N}^{\circ} 1$ and $\mathrm{N}^{\circ} 2$ and was therefore selected for further evaluation. Assay $\mathrm{N}^{\circ} 3$ had lower $\mathrm{Ct}$ values and higher relative fluorescence than the other two assays for all samples evaluated. As expected, the $\mathrm{Ct}$ value differences between assays $\mathrm{N}^{\circ} 1$ and $\mathrm{N}^{\circ} 3$ were higher between samples from O. mykiss

Table 1 Alternative assays used to compare efficiency and transversality of detection

\begin{tabular}{|c|c|c|c|c|}
\hline Assay $\mathrm{N}^{\circ}$ & Assay name & Name & Sequence $\left(5^{\prime}-3^{\prime}\right)$ & Reference \\
\hline 1 & & ELF1a For & CCCCTCCAGGACGTTTACAAA & [14] \\
\hline 1 & ELF1a & ELF1a Rev & CACACGGCCCACAGGTACA & [14] \\
\hline 1 & & FAM-ELF1a & FAM- ATCGGCGGTATTGGAAC & [14] \\
\hline 2 & & ELF1a GIM-1-For & CCCCTCCAGGAYGTYTACAAA & This work \\
\hline 2 & ELF1a GIM-1 & ELF1a GIM-1 Rev & CACACGGCCCACRGGTACW & This work \\
\hline 2 & & FAM- ELF1a GIM & FAM-ATCGGYGGTAT $+\mathrm{T}+\mathrm{G}+\mathrm{G}+\mathrm{A}+\mathrm{AC}-\mathrm{BHQ}$ & This work \\
\hline 3 & & ELF1a GIM-2 For & GCCCCTCCAGGAYGTYTACAA & This work \\
\hline 3 & ELF1a GIM-2 & ELF a GIM-2 Rev & CCACACGGCCCACRGGTAC & This work \\
\hline 3 & & FAM-ELF1a GIM & FAM-ATCGGYGGTAT $+\mathrm{T}+\mathrm{G}+\mathrm{G}+\mathrm{A}+\mathrm{AC}-\mathrm{BHQ}$ & This work \\
\hline
\end{tabular}

Assay $\mathrm{N}^{\circ} 1$ (ELF1a) is the current assay. Assays $\mathrm{N}^{\circ} 2$ (ELF1a GIM-1) and $\mathrm{N}^{\circ} 3$ (ELF1a GIM-2), use alternative primers and probes designed to test the objectives of this study. The FAM-ELF1a probe has MGB, and the FAM-ELF1a-GIM probe has LNA residues, denoted by a + symbol before the corresponding nucleotide. 
Table 2 Comparative performance of the assays in different species of salmonid tested

\begin{tabular}{|c|c|c|c|c|c|c|}
\hline & \multicolumn{2}{|c|}{ ELF1 $a$} & \multicolumn{2}{|c|}{ ELF1a GIM-1 } & \multicolumn{2}{|c|}{ ELF1a GIM-2 } \\
\hline & $\mathrm{Ct}$ value & $\Delta \mathrm{Rn}$ & $\mathrm{Ct}$ value & $\Delta \mathrm{Rn}$ & Ct value & $\Delta \mathrm{Rn}$ \\
\hline O. mykiss & $32.31 \pm 0.88$ & $0.201 \pm 0.039$ & $26.49 \pm 0.25$ & $0.811 \pm 0.019$ & $21.43 \pm 0.080$ & $1.498 \pm 0.017$ \\
\hline O. kisutch & $31.10 \pm 0.36$ & $0.238 \pm 0.021$ & $27.86 \pm 0.17$ & $0.686 \pm 0.043$ & $22.71 \pm 0.109$ & $1.353 \pm 0.019$ \\
\hline S. salar & $28.55 \pm 0.43$ & $0.307 \pm 0.021$ & $29.18 \pm 0,14$ & $0.519 \pm 0.008$ & $23.56 \pm 0.017$ & $1.232 \pm 0.001$ \\
\hline
\end{tabular}

The comparison was made based on the $\mathrm{Ct}$ values and relative fluorescence intensities $(\Delta \mathrm{Rn})$. The probes used in this comparison were depleted of either MGB or LNA. The data are shown as a Ct value \pm standard deviation and $\Delta R n \pm$ standard deviation $(n=3)$.

and $O$. kisutch species. This is because assay $\mathrm{N}^{\circ} 3$ takes into account the nucleotide variability in the amplification region for this genus, thereby avoiding the mismatches observed in assay $\mathrm{N}^{\circ} 1$. In the same way, samples from $S$. salar showed slighter differences in $\mathrm{Ct}$ values between assays.

Although both alternative assays ( $\mathrm{N}^{\circ} 2$ and $\left.\mathrm{N}^{\circ} 3\right)$ considered the existing nucleotide variability of the species tested, the performance of assay $\mathrm{N}^{\circ} 3$ was notoriously better than that of assay $\mathrm{N}^{\circ} 2$. We hypothesize that this effect may be a result of a structural interference between the primer and the probe and not primarily of the template mismatches.

The next step in the evaluation was to consider the design of a more stable assay by increasing the Tm of the probes and thus increasing the annealing stability between the probe and the template. To achieve this objective, MGB was used on the probe of the ELF1 $\alpha$ assay, as reported previously [13] and Locked Nucleic Acid (LNA) was used on the probe of the ELF $1 \alpha$ GIM- 2 assay. The comparison was made between assay $\mathrm{N}^{\circ} 3$ (selected new assay) and the original assay $\mathrm{N}^{\circ} 1$ (reference assay) considering samples derived from both tissues and cell cultures from different species of salmonids. Table 3 summarizes our results, showing that, as expected, cell culture and tissues samples from $S$. salar had lower $\Delta \mathrm{Ct}$ values between assays (Ct value ELF1 $\alpha$ - Ct value ELF1 $\alpha$ GIM-2), while cell culture and tissues samples from the Oncorhynchus genus had higher differences in $\mathrm{Ct}$ values between assays and therefore a higher $\Delta \mathrm{Ct}$. The largest differences, however, were observed between samples derived from $O$. tshawytscha, where a maximal $\Delta \mathrm{Ct}$ value of 11.101 was obtained from tissue-derived samples.

An additional analysis can be performed when we compare the results from Table 2 (probes without the enhancer Tm system) with the results from Table 3 (probes with the enhancer Tm system). In fact, differences between assays $\mathrm{N}^{\circ} 1$ and $\mathrm{N}^{\circ} 3$, shown in Table 2, gave a $\Delta \mathrm{Ct}$ value of 10.88 for the $O$. mykiss tissue sample, whereas in Table 3 , the $\Delta \mathrm{Ct}$ value was diminished to 5.27. This is a powerful demonstration that the enhancers, in addition to increasing Tm values, stabilize the probe-template annealing and, as a result, render the assay more robust.

Although only LNA was used in the probe of the ELF1 $\alpha$ GIM-2 assay, we would expect a similar result when using MGB as an enhancer.

The evaluation of the efficiency of assay $\mathrm{N}^{\circ} 3$ for all samples tested is shown in Table 3. All values for the RT-qPCR reactions fell within the suitable experimental range (90\%-110\%) [27].

\section{Evaluation of field samples}

The final evaluation compared assay $\mathrm{N}^{\circ} 3$ (ELF1 $\alpha$ GIM-2) with the original assay $\mathrm{N}^{\circ} 1$ (ELF1 $\left.\alpha\right)$, using the same distribution of LNA as a system to increase the probe Tm value in both assays. Field samples from S. Salar $(\mathrm{n}=98)$, O. mykiss $(\mathrm{n}=97)$ and O. kisutch $(\mathrm{n}=82)$ were obtained from different farms located in the south of Chile, and parallel assays were run under the same RT-qPCR

Table 3 Comparison of differences in Ct values in tissue and cell culture samples from different salmonid species

\begin{tabular}{|c|c|c|c|c|c|c|}
\hline Samples & Type & Specie & $\begin{array}{c}\text { ELF1a } \\
\text { Ct Value }\end{array}$ & $\begin{array}{c}\text { ELF1a GIM-2 } \\
\text { Ct Value }\end{array}$ & $\begin{array}{c}\Delta \mathrm{Ct} \\
\text { value }\end{array}$ & $\begin{array}{c}\text { Eficiency } \\
\text { (\%) }\end{array}$ \\
\hline ASK-1 & Cell culture & S. salar & $28.134 \pm 0.149$ & $25.381 \pm 0.114$ & 2.753 & 96.65 \\
\hline SHK-1 & Cell culture & S. salar & $27.198 \pm 0.204$ & $24.237 \pm 0.078$ & 2.961 & 92.78 \\
\hline RTS11 & Cell culture & O. mykiss & $30.384 \pm 0.338$ & $25.028 \pm 0.191$ & 5.356 & 96.52 \\
\hline CHSE-214 & Cell culture & O. tshawytscha & $32.768 \pm 0.421$ & $24.354 \pm 0.262$ & 8.414 & 93.64 \\
\hline GIMCP & Tissue & S. salar & $29.235 \pm 0.107$ & $25.297 \pm 0.205$ & 3.938 & 96.90 \\
\hline GIM017 & Tissue & O. mykiss & $33.467 \pm 0.63$ & $26.194 \pm 0.199$ & 5.273 & 96.16 \\
\hline GIM025 & Tissue & O. kisutch & $29.447 \pm 0.177$ & $24.693 \pm 0.146$ & 4.754 & 101.24 \\
\hline GIM496 & Tissue & O. tshawytscha & $36.494 \pm 0.217$ & $25.393 \pm 0.161$ & 11.101 & 97.22 \\
\hline
\end{tabular}

The $\Delta \mathrm{Ct}$ value was calculated (Ct value ELF1a - Ct value ELF1a GIM-2). 
conditions (reagent mix, software setup, and data analysis). Four (out of 82) samples from O. kisutch were withdrawn from the analysis because they could interfere with the correct analysis because they displayed $\Delta \mathrm{Ct}$ values over 9 , and one of them had a $\Delta \mathrm{Ct}$ value of 16 . This result suggested that this might be due to several mismatches between the template and the primers and the probe of the ELF1 $\alpha$ assay.

An integral analysis of the data shows that, similar to previous results, $S$. salar samples displayed smaller differences between assays $\mathrm{N}^{\circ} 3$ and $\mathrm{N}^{\circ} 1$, which was expected, as the latter was designed to specifically fit $\mathrm{S}$. salar sequences. Samples from O. mykiss and O. kisutch displayed higher differences in $\mathrm{Ct}$ values, as seen in Figure 2. Therefore, $\Delta \mathrm{Ct}$ values depend on the salmonid species analyzed. Furthermore, no significant differences in $\Delta \mathrm{Ct}$ values were observed between the O. mykiss and O. kisutch samples analyzed.

Figure 3 shows the Ct values displayed in each assay from field samples of the three salmonid species. As expected, the new assay $\mathrm{N}^{\circ} 3$ (ELF1 $\alpha$ GIM-2) displayed no significant differences among the $\mathrm{Ct}$ values obtained (Figure 3B). When the original assay $\mathrm{N}^{\circ} 1(\mathrm{ELF} 1 \alpha)$ was used, significant differences were observed between $\mathrm{Ct}$ values of samples from the S. salar and Oncorhynchus species (Figure 3A).

These differences in $\mathrm{Ct}$ values reveal the importance in diagnoses of an adequate endogenous control. Indeed, using assay $\mathrm{N}^{\circ} 1$, samples derived from $S$. salar display $\mathrm{Ct}$ values within a valid range for diagnostic purposes, whereas samples from the Oncorhynchus group display higher $\mathrm{Ct}$ values, some of which were beyond the valid

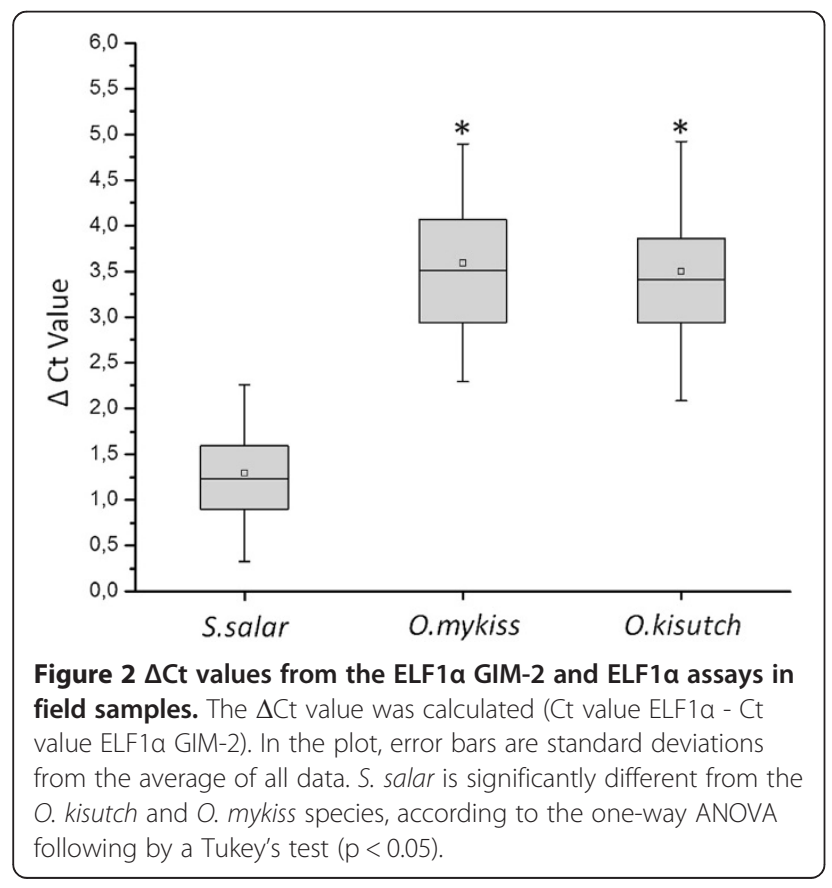

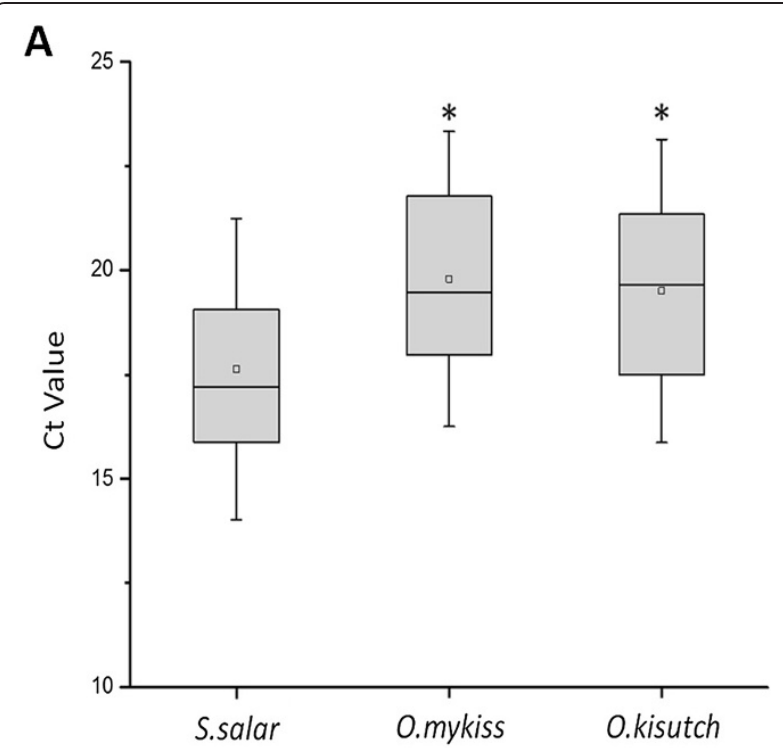

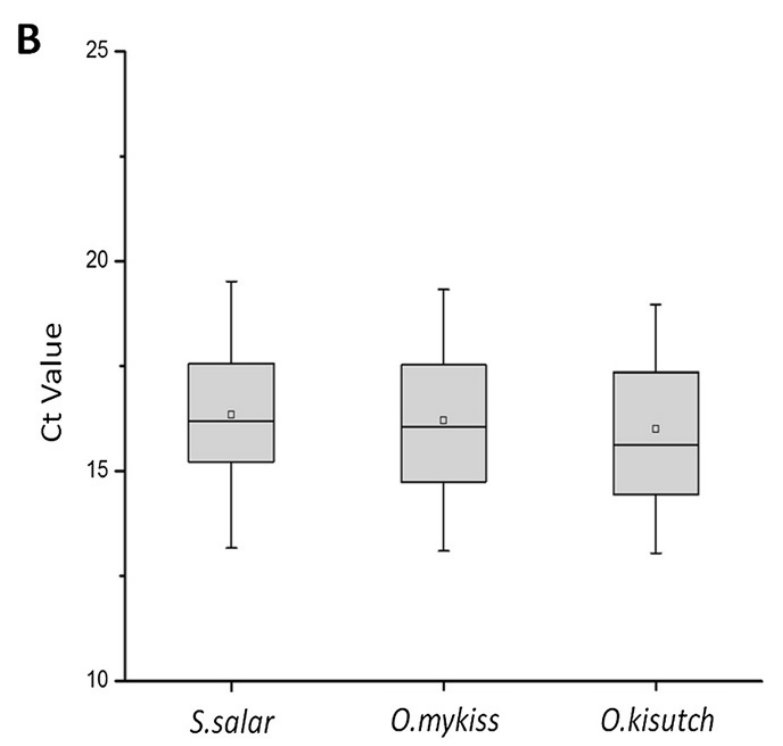

Figure 3 Distribution of $\mathrm{Ct}$ values of field samples. ELF1a assay (A) and the ELF1a GIM-2 assay (B). The ELF1a GIM-2 assay does not show significant differences between the three salmonid species, whereas the ELF1a assay shows a significant difference between the S. salar and Oncorhynchus species samples ( $*$ ). Statistical analysis was performed using one-way ANOVA and Tukey's test $(p<0.05)$.

range for diagnoses. Thus, incorrect diagnoses may occur as a result of a weak detection assay design; however, this effect is corrected in the new assay.

\section{Conclusions}

Here we identified nucleotide variability in the amplified region of ELF1 $\alpha$, which causes highly variable results when the ELF1 $\alpha$ assay is used as an endogenous control for Oncorhynchus species. Using this information, we have designed and improved a single reliable and efficient assay (ELF1 $\alpha$ GIM-2), driven to an endogenous cellular quality 
control, to be used in RT-qPCR diagnostics of pathogenic agents in tissue samples from the salmonid species analyzed in this work.

\section{Methods Samples}

Tissue samples analyzed were obtained from the kidneys of Salmo salar, Oncorhynchus mykiss, Oncorhynchus kisutch and Oncorhynchus tshawytscha according to official procedures established by Sernapesca, the Chilean government institution in charge of animal health surveillance in aquaculture and fisheries. Salmonid cell lines ASK-1, Atlantic Salmon Kidney (ATCC; CRL-2747) [28], SHK-1, Atlantic Salmon Head Kidney [29], CHSE-214, Chinook Salmon Embryo (ATCC; CRL-1681) [30] and RTS11, rainbow trout monocytes/macrophages cell line [31], were used as verification controls.

\section{Ethical statement}

Tissue samples from fish were obtained from the surveillance program for fish disease in Chile. Fish were not killed for the purpose of this study. All sampling was performed according the regulations of Sernapesca (Chilean government institution in charge of fish health) and carried out in strict compliance with the recommendations of Chapter 7.4 of the Aquatic Animal Health Code of the World Organization for Animal Health. Every effort was made to minimize animal suffering in all procedures.

\section{Total RNA isolation}

Tissue samples were preserved in RNAlater (Ambion) to be transported from the fish farms to the laboratory. Total RNA from the tissue samples and cell culture samples were isolated using the RNeasy Mini Kit (Qiagen), according to the standard protocols recommended by the supplier. Prior to the isolation of RNA, tissue samples were homogenized using a MagnaLyser device (Roche) for $30 \mathrm{sec}$ at $6500 \mathrm{rpm}$. RNA samples were stored at $-80^{\circ} \mathrm{C}$ until use.

\section{cDNA synthesis}

RNA samples for sequencing were reverse transcribed using the SuperScript III kit (Invitrogen), according to the protocols recommended by the supplier. Briefly, approximately $1 \mu \mathrm{g}$ of total RNA was added to the mix, which contained $0.5 \mu \mathrm{L}$ of dNTPs $(10 \mathrm{mM}), 2 \mu \mathrm{L}$ of $5 \mathrm{X}$ First Strand Buffer, $0.5 \mu \mathrm{L}$ of DTT $(0.1 \mathrm{M}), 0.5 \mu \mathrm{L}$ of SuperScript III reverse transcriptase enzyme, and $1 \mu \mathrm{L}$ of Random Primers $(100 \mu \mathrm{M})$ (Fermentas) in a final volume of $10 \mu \mathrm{L}$. Reactions were incubated at $25^{\circ} \mathrm{C}$ for $10 \mathrm{~min}, 50^{\circ} \mathrm{C}$ for $1 \mathrm{~h}$, and $75^{\circ} \mathrm{C}$ for $15 \mathrm{~min}$. The final cDNA was diluted 3 -fold before being used as a template in PCR.

\section{PCR and sequencing analyses}

All PCR reactions for sequencing purposes were performed using external primers ELF1 $\alpha$ Ext For 5'-ATG GGC TGG TTC AAG GGA TG-3' and ELF1 $\alpha$ Ext Rev 5'-CGT GGT GCA TCT CCA CAG AC-3'. PCR was performed using the Go Taq Flexi Polymerase Kit (Promega). Each reaction had a final volume of $25 \mu \mathrm{L}$ and consisted of $5 \mu \mathrm{L}$ of $5 \mathrm{X}$ Colorless Flexi Buffer, $0.5 \mu \mathrm{L}$ of dNTP $(10 \mathrm{mM}), 3 \mu \mathrm{L}$ of $\mathrm{MgCL}_{2}(25 \mathrm{mM}), 0.2 \mu \mathrm{L}$ of Go Taq DNA Polymerase, each primer at a final concentration of $400 \mathrm{nM}, 11.3 \mu \mathrm{L}$ of nuclease-free water (Invitrogen), and $4 \mu \mathrm{L}$ of the diluted cDNA. The PCR program used consisted of an initial denaturation for $2 \mathrm{~min}$ at $95^{\circ} \mathrm{C}$, followed by 40 cycles of denaturation for $30 \mathrm{sec}$ at $94^{\circ} \mathrm{C}$, primer annealing for $30 \mathrm{sec}$ at $60^{\circ} \mathrm{C}$, and elongation for $1 \mathrm{~min}$ at $72^{\circ} \mathrm{C}$. The final elongation step was run for $5 \mathrm{~min}$ at $72^{\circ} \mathrm{C}$. The resulting amplicons were resolved by agarose gel electrophoresis, and the target bands were purified from the gel using the E.Z.N.A Gel Extraction Kit (Omega Biotek), according to the protocols recommended by the supplier. The purified PCR products were quantified and then sequenced at Macrogen Inc. (Korea) with the same primers used in the PCR reaction. Sequences were interpreted using the Bioedit Software [24] and the multiple alignments were performed via ClustalW [23].

\section{Real-time RT-qPCR}

Real-time PCR amplifications were performed using the Super Script III Platinum One-Step Quantitative RT-PCR System Kit (Invitrogen) and the StepOnePlus Real-time PCR System thermocycler (Applied Biosystems). Primer sets and assay names are listed in Table 1 . Each reaction was carried out in a final volume of $20 \mu \mathrm{L}$. Primers were at a final concentration of $1 \mu \mathrm{M}$, and hydrolysis probes were at a final concentration of $0.3 \mu \mathrm{M}$. The reactions contained the passive reference dye, ROX. One cycle of reverse transcription was run for $15 \mathrm{~min}$ at $50^{\circ} \mathrm{C}, 1$ cycle of denaturation for $2 \mathrm{~min}$ at $95^{\circ} \mathrm{C}$, and 45 cycles of denaturation for $15 \mathrm{sec}$ at $95^{\circ} \mathrm{C}$, followed by annealing and elongation for $1 \mathrm{~min}$ at $60^{\circ} \mathrm{C}$. Real-time PCR efficiencies were calculated from the slope according to the established equation $\mathrm{E}=10^{(-1 / \mathrm{slope})}$ [32].

\section{Field sample evaluation}

Samples consisted of organ pools (heart, gill and kidney) from 98 specimens of S. salar, 97 of O. kisutch and 82 of O. mykiss. Samples were fixed with RNAlater in a tissue: fixator ratio of $1: 10$ and stored at $6-8^{\circ} \mathrm{C}$ prior to analysis. The fixed samples were homogenized using Precellys device (Bertin Technologies). The homogenized samples were centrifuged by 2 min. at 13.000 r.p.m (pico 17, Thermo). The supernatants were purified for RNA using a high purity viral nucleic acid kit (Roche) according to 
the manufacturer's instructions. The purified RNA was analyzed using the RT-qPCR protocols described previously.

\section{Statistical analysis}

The statistical analyses were performed using OriginPro V8.5 software. Comparisons between $\mathrm{Ct}$ values or $\Delta \mathrm{Ct}$ values were performed using one way ANOVA followed by a Tukey's tests $(\mathrm{P}<0.05)$, to denote significant differences.

\section{Abbreviations}

ELF1a: Elongation factor 1 alpha; PCR: Polymerase chain reaction;

RT-qPCR: Real-time reverse transcription polymerase chain reaction.

\section{Competing interests}

The authors declare that they have no competing interests.

\section{Authors' contributions}

DS and SM designed the experiments, performed data analysis and drafted the manuscript. $\mathrm{HB}$ and $\mathrm{HG}$ were in charge of the field samples in the experimental part. AL was in charge of the sampling process and designed the experiments. All authors have read and approved the final manuscript.

\section{Acknowledgements}

The authors would like to thank Dannia Gimenez, Macarena Jimenez and Alicia Millon, for their skillful technical assistance with the nucleic acid isolation from tissue, RT-qPCR, and quality control in the experiment performed in the Pontificia Universidad Católica de Valparaíso. Funding for this research was provided by CORFO-Innova grant number 09MCSS-6725. We also thank Sernapesca for the kind support.

\section{Author details}

'Laboratorio de Genética e Inmunología Molecular, Instituto de Biología, Facultad de Ciencias, Pontificia Universidad Católica de Valparaíso, Valparaíso, Chile. ${ }^{2}$ Laboratorio de Patógenos Acuícolas, Núcleo Biotecnología Curauma, Pontificia Universidad Católica de Valparaíso, Valparaíso, Chile. ${ }^{3} \mathrm{ADL}$ Diagnostic Chile Ltda., Laboratorio de Diagnóstico y Biotecnología, Puerto Montt, Chile. ${ }^{4}$ Servicio Nacional de Pesca (Sernapesca), Valparaíso, Chile. ${ }^{5}$ Fraunhofer Chile Research Foundation, Center For Systems Biotechnology, Santiago, Chile. ${ }^{6}$ Present Address: Department Animal Science, Fish Health, Aarhus University, Hangøvej 2, 8200 Aarhus N, Denmark.

Received: 25 February 2013 Accepted: 3 September 2013 Published: 16 September 2013

\section{References}

1. Schreck CB: Stress and fish reproduction: the roles of allostasis and hormesis. Gen Comp Endocrinol 2010, 165(3):549-556.

2. Sindermann CJ: Disease in marine aquaculture. Helgol Mar Res 1984, 37(1):505-530

3. Bustin SA: Absolute quantification of mRNA using real-time reverse transcription polymerase chain reaction assays. $J$ Mol Endocrinol 2000, 25(2):169-193.

4. Matejusova I, McKay P, Bland F, Snow M: Application of a sensitive, specific and controlled real time PCR assay to surveillance indicates a low prevalence of viral haemorrhagicsepticaemia virus (VHSV) in wild herring, Clupeaharengus L., in Scottish waters. J Fish Dis 2010, 33(10):841-847.

5. Purcell MK, Hart SA, Kurath G, Winton JR: Strand-specific, real-time RT-PCR assays for quantification of genomic and positive-sense RNAs of the fish rhabdovirus, Infectious hematopoietic necrosis virus. J Virol Methods 2006, 132(1):18-24.

6. Hodneland K, Endresen C: Sensitive and specific detection of Salmonidalphavirus using real-time PCR (TaqMan). J Virol Methods 2006, 131(2):184-192.

7. Karatas S, Mikalsen J, Steinum TM, Taksdal T, Bordevik M, Colquhoun DJ: Real time PCR detection of Piscirickettsiasalmonis from formalin-fixed paraffin-embedded tissues. J Fish Dis 2008, 31(10):747-753.

8. Corbeil S, McColl KA, Crane MSJ: Development of a TaqMan quantitative PCR assay for the identification of Piscirickettsiasalmonis. Bull Eur Assn Fish P 2003, 23(3):95-101.
9. Olivares J, Marshall SH: Determination of minimal concentration of Piscirickettsiasalmonis in water columns to establish a fallowing period in salmon farms. J Fish Dis 2010, 33(3):261-266.

10. Bruno D, Collet B, Turnbull A, Kilburn R, Walker A, Pendrey D, Mclntosh A, Urquhart K, Taylor G: Evaluation and development of diagnostic methods for Renibacteriumsalmoninarum causing bacterial kidney disease (BKD) in the UK. Aquaculture 2007, 269(1-4):114-122.

11. Snow M, McKay P, McBeath AJA, Black J, Doig F, Kerr R, Cunningham CO, Nylund A, Devold M: Development, application and validation of a taqman ${ }^{\oplus}$ real-time RT-PCR assay for the detection of infectious salmon anaemia virus(ISAV) in atlantic salmon(Salmosalar). Dev Biol 2006, 126:133-145.

12. Bowers RM, Lapatra SE, Dhar AK: Detection and quantitation of infectious pancreatic necrosis virus by real-time reverse transcriptase-polymerase chain reaction using lethal and non-lethal tissue sampling. J Virol Methods 2008, 147(2):226-234.

13. Bland F, Mclntosh R, Bain N, Snow M: Development and validation of a range of endogenous controls to support the implementation of practical Taqman real time PCR-based surveillance for fish diseases within aquaculture. J Fish Dis 2012, 35:447-454.

14. Moore $\sqcup$, Somamoto T, Lie KK, Dijkstra JM, Hordvik I: Characterisation of salmon and trout CD8 [alpha] and CD8 [beta]. Mol Immunol 2005, 42(10):1225-1234.

15. Ingerslev $\mathrm{HC}$, Pettersen $\mathrm{EF}$, Jakobsen RA, Petersen $\mathrm{CB}$, Wergeland $\mathrm{HI}$ : Expression profiling and validation of reference gene candidates in immune relevant tissues and cells from Atlantic salmon (Salmosalar L.). Mol Immunol 2006, 43(8):1194-1201.

16. Jorgensen SM, Kleveland EJ, Grimholt U, Gjoen T: Validation of reference genes for real-time polymerase chain reaction studies in Atlantic salmon. Mar Biotechnol 2006, 8(4):398-408.

17. Peña AA, Bols NC, Marshall SH: An evaluation of potential reference genes for stability of expression in two salmonid cell lines after infection with either Piscirickettsiasalmonis or IPNV. BMC research notes 2010, 3(1):101.

18. Lovoll M, Austbo L, Jorgensen JB, Rimstad E, Frost P: Transcription of reference genes used for quantitative RT-PCR in Atlantic salmon is affected by viral infection. Vet Res 2011, 42(1):8.

19. SuB B, Flekna G, Wagner M, Hein I: Studying the effect of single mismatches in primer and probe binding regions on amplification curves and quantification in real-time PCR. J Microbiol Methods 2009, 76(3):316-319.

20. Jiang Z, Wang Z, Kunej T, Williams GA, Michal JJ, Wu XL, Magnuson NS: A novel type of sequence variation: multiple-nucleotide length polymorphisms discovered in the bovine genome. Genetics 2007, 176(1):403-407.

21. Vignal A, Milan D, SanCristobal M, Eggen A: A review on SNP and other types of molecular markers and their use in animal genetics. Genet Sel Evol 2002, 34(3):275-306

22. Kerkel K, Spadola A, Yuan E, Kosek J, Jiang L, Hod E, Li K, Murty W, Schupf N, Vilain E: Genomic surveys by methylation-sensitive SNP analysis identify sequence-dependent allele-specific DNA methylation. Nat Genet 2008, 40(7):904-908

23. Edgar RC: MUSCLE: multiple sequence alignment with high accuracy and high throughput. Nucleic Acids Res 2004, 32(5):1792-1797.

24. Hall TA: BioEdit: a user-friendly biological sequence alignment editor and analysis program for Windows 95/98/NT. Nucleic Acids Symp Ser 1999, 41:95-98.

25. Klungthong C, Chinnawirotpisan P, Hussem K, Phonpakobsin T, Manasatienkij W, Ajariyakhajorn C, Rungrojcharoenkit K, Gibbons RV, Jarman RG: The impact of primer and probe-template mismatches on the sensitivity of pandemic influenza $\mathrm{A} / \mathrm{H} 1 \mathrm{~N} 1 / 2009$ virus detection by real-time RT-PCR. J Clin Virol 2010, 48(2):91-95.

26. Kibbe WA: OligoCalc: an online oligonucleotide properties calculator. Nucleic Acids Res 2007, 35(suppl 2):W43-W46.

27. Bustin SA, Benes V, Garson JA, Hellemans J, Huggett J, Kubista M, Mueller R, Nolan T, Pfaffl MW, Shipley GL: The MIQE guidelines: minimum information for publication of quantitative real-time PCR experiments. Clin Chem 2009, 55(4):611-622.

28. Devold M, Krossoy B, Aspehaug V, Nylund A: Use of RT-PCR for diagnosis of infectious salmon anaemia virus (ISAV) in carrier sea trout Salmotrutta after experimental infection. Dis Aquat Organ 2000, 40(1):9-18.

29. Dannevig BH, Falk K, Namork E: Isolation of the causal virus of infectious salmon anaemia (ISA) in a long-term cell line from Atlantic salmon head kidney. J Gen Virol 1995, 76(6):1353-1359. 
30. Lannan CN, Winton JR, Fryer JL: Fish cell lines: establishment and characterization of nine cell lines from salmonids. In Vitro Cell Dev-PI 1984, 20(9):671-676.

31. Ganassin RC, Bols NC: Development of a monocyte/macrophage-like cell line, RTS11, from rainbow trout spleen. Fish Shellfish Immun 1998, 8(6):457-476.

32. Pfaffl MW: A new mathematical model for relative quantification in real-time RT-PCR. Nucleic Acids Res 2001, 29(9):e45.

doi:10.1186/1746-6148-9-183

Cite this article as: Sepúlveda et al:: Design and evaluation of a unique RT-qPCR assay for diagnostic quality control assessment that is applicable to pathogen detection in three species of salmonid fish. BMC Veterinary Research 2013 9:183.

\section{Submit your next manuscript to BioMed Central and take full advantage of:}

- Convenient online submission

- Thorough peer review

- No space constraints or color figure charges

- Immediate publication on acceptance

- Inclusion in PubMed, CAS, Scopus and Google Scholar

- Research which is freely available for redistribution 